\title{
Bioefficacy of fungicides, plant extracts and essential oils against Exserohilum turcicum (Pass.) Leonard and Suggs causing Northern leaf blight of maize
}

\author{
Bhagyashree Bhatt* \\ Department of Plant Pathology, G. B. Pant University of Agriculture and Technology, \\ Pantnagar, U. S. Nagar-263145 (Uttarakhand), India \\ Pradeep Kumar \\ Department of Plant Pathology, G. B. Pant University of Agriculture and Technology, \\ Pantnagar, U. S. Nagar-263145 (Uttarakhand), India
}

*Corresponding author. E-mail: bhagyashreebhatt15@gmail.com

\begin{abstract}
Eight fungicides, ten botanicals and ten essential oils were taken for their in vitro evaluation against Exserohilum turcicum (Pass.) Leonard and Suggs incited of Northern Leaf Blight of Maize. Among all the tested fungicides (Azoxystrobin 23\%, Thiophenate methyl $75 \%$, Propiconazole 25\%, Tebuconazole 25.9\%, Captan 50\%, Zineb 75\%, Cymoxanil $8 \%$ +Mancozeb $64 \%$ and Zineb $68 \%+$ Hexaconazole $4 \%$ ), propiconazole $25 \%$ showed maximum inhibition of mycelial growth (92.22\%) under in vitro conditions at $5 \mathrm{ppm}$ concentration. Among all the tested botanicals Heena (Lawsonia inermis) was found to be most effective in inhibiting mycelial growth $(71.11 \%)$ at $10 \%$ concentration. Lemon tulsi oil was found best in inhibiting mycelial growth $(71.30 \%)$ of Exserohilum turcicum, among all the tested essential oils at $50 \mathrm{ppm}$ concentration. Fungicides, plant extracts and essential oils showing good results under in vitro conditions were tested under glasshouse conditions. Foliar spray of Propiconazole 25\%EC@0.1\% showed reduced disease incidence $(23.33 \%)$ compared to control $(46.33 \%)$. Application of $5 \%$ of Heena extracts reduced the disease incidence $(26.67 \%)$. Plants when sprayed with Lemon tulsi oil showed reduced disease incidence $(24.17 \%)$. The study reveals that not only the fungicides but also the natural plant extracts can greatly contribute to reduce the incidence of disease because of the antifungal compounds present in plants.
\end{abstract}

Keywords: Exserohilum turcicum, maize, fungicides, plant extracts, essential oils.

\section{Article Info}

DOI:10.31018/jans.v11i2.2030 Received: February 26, 2019 Revised: March 23, 2019 Accepted: April 5, 2019

\section{How to Cite}

Bhatt, B. and Kumar, P. (2019). Bioefficacy of fungicides, plant extracts and essential oils against Exserohilum turcicum (Pass.) Leonard and Suggs causing Northern leaf blight of maize. Journal of Applied and Natural Science, 11 (2): $257-262$ https:// doi.org/10.31018/ jans.v11i2.2030

\section{INTRODUCTION}

Exserohilum turcicum is one of the most important fungal pathogen of maize. The pathogen causes Northern leaf blight disease of maize which is one of the most devastating diseases as it results in reduction of grain yield by 28 to 91 per cent (Carlos, 1997; Kachapur and Hegde, 1988 and Harlapur et al., 2007). The pathogen overwinters in the crop residues such as infected corn husks, leaves and other plant parts (Smith et al. 2004). Thus various cultural practices like field sanitation, crop rotation and tillage can play a major role in the management of disease. Though genetic resistance to the pathogenic races have been developed but due to multiple races of the pathogen and race shifts, breeders may face problem in integrating multiple resistance genes and it is also very time consuming. The use of fungicides in integration with all the cultural practices and resistant varieties may lead to a better management practice (Wise, 2011). Since excess use of fungicides is also not preferred due to environmental pollution caused by chemicals, identification of more environment friendly and natural compounds showing significant control over the pathogen can be taken into consideration as a management component. Though it is generally observed that use of natural antifungal compounds cannot completely replace the chemical fungicides but they can reduce the chemical load on the environment which is serious issue in the present scenario. Keeping in view, the present investigation is aimed at evaluation of fungicides, botanicals and essential oils against $E$. turcicum.

\section{MATERIALS AND METHODS}

Isolation of pathogen: The leaves of maize plant showing Northern leaf blight symptoms were collected from the field. The infected part of leaf was cut with help of sterilised blade into pieces of 2$3 \mathrm{~mm}$ size having half healthy and half diseased tissues. The small pieces were sterilised with Sodium hypochlorite solution $2 \%$ for 30 seconds and thoroughly washed in sterilised water three times. 
Bhatt, B. and Kumar, P. / J. Appl. \& Nat. Sci. 11(2): 257- 262 (2019)

Then the pieces were placed between two layers of sterilized blotter paper to remove excess of water. These pieces were then transferred to slants and Petri plates containing Potato Dextrose Agar (PDA) medium inside laminar flow chamber under aseptic conditions. The inoculated plates were incubated at $28 \pm 2^{\circ} \mathrm{C}$ for 7 days and then subcultured in fresh PDA.

Purification of fungus by single spore isolation method: Spore suspension was prepared by adding $5 \mathrm{ml}$ sterilised distilled water to plate containing seven days old culture and was filtered with muslin cloth to get spores in a beaker. The suspension obtained was then diluted to reduce the spore count to get $10-15$ spores per microscopic field from the suspension.

One $\mathrm{ml}$ of suspension was taken and then was uniformly spread on 2 per cent solidified water agar plates and incubated at $28 \pm 2^{0} \mathrm{C}$ for 12 hours. The plates were then examined under stereoscopic microscope and single spores were marked by using marker. The marked spores were then picked up by cork borer and aseptically transferred to PDA medium in sterilized petriplates for further growth and incubated at $28 \pm 2^{\circ} \mathrm{C}$. The pure culture obtained, was used for further studies.

In vitro evaluation of fungicides: In vitro, efficacy of eight different fungicides against $E$. turcicum was studied by using poison food technique (Nene and Thapliyal, 1979). Four systemic and four non systemic fungicides were tested against $E$. turcicum on the potato dextrose agar media using poison food technique under in vitro conditions. The systemic fungicides were tested at 5 , $10,20,30$ and 50ppm concentrations where as non systemic fungicides were evaluated at 50 , $100,200,500$ and 1000ppm concentrations. Systemic fungicides viz Azoxistrobin 23\%SC (Amistar), Thiophenate methyl 75\%WP(Roko), Propiconazole 25\%EC (Dhan), Tebuconazole $25.9 \%$ EC(Folicur) were evaluated. Non systemic fungicides viz Captan50\%WP(Captaf), Zineb75\% WP(Indofil Z-78), Cymoxanil (8\%)+Mancozeb (64\%) 72 WP (Curzate M8), Zineb(64\%) +Hexaconazole(4\%)72 WP (Avatar). Desired concentrations of fungicides were calculated and were prepared using sterilised distilled water. Fungicide solution prepared was then mixed thoroughly in $20 \mathrm{ml}$ sterilised PDA and poured into $90 \mathrm{~mm}$ sterilised petriplates. Non toxicated media was poured in sterilised petri plates and was taken as control. After solidification of media a $5 \mathrm{~mm}$ disc of seven days old culture of the test pathogen was cut with a sterile cork borer and placed in centre of each petri plate. The petri plates were incubated at $28 \pm 2^{\circ} \mathrm{C}$. After seven days of incubation the radial growth was measured. The percent inhibition in growth was determined with the help of mean colony diameter and calculated by using the following formula (Vincent, 1947).
Per cent inhibition $=\mathrm{X}-\mathrm{Y} / \mathrm{X} \times 100$ ...Eq. 1 Where, $\mathrm{X}=$ Colony diameter in control, $\mathrm{Y}=$ Colony diameter in treated medium

In vitro evaluation of botanicals: The leaf extracts of Eucalyptus, Lantana, Ashok, Marigold, Duranta, Aloevera, Heena and rhizome extracts of Ginger and Turmeric were extracted using aqueous extract method. Fifty grams of thoroughly washed leaves or rhizome were macerated with $50 \mathrm{ml}$ of sterile distilled water in a blender for 10 minutes. The extract was filtered through muslin cloth and the supernatant obtained was used as standard plant extract solution (100\%). Plant extracts were evaluated at $5,10,15$ and $20 \%$ concentration by diluting with sterilised distilled water. Desired amount of plant extract was added in $20 \mathrm{ml}$ sterilised PDA and poured into petriplates. The $5 \mathrm{~mm}$ disc of test pathogen grown on PDA medium was placed at centre of petriplates containing different concentration of the poisoned medium and incubated at $28 \pm 2{ }^{\circ} \mathrm{C}$. Three replications were maintained and radial growth was taken when maximum growth occurred in the control plates. The inhibition per cent of radial growth over the control was calculated by using formula given by Vincent (1947).

In vitro evaluation of essential oils: Ten essential oils viz Ginger, Clove, Citronella, Lemon tulsi, Palmarosa, Geranium, Turmeric, Lemon grass, Patchouli and Eucalypus were evaluated in vitro against the test pathogen using poison food technique. All the oils were obtained from Central Institute of Medicinal and Aromatic Plants (CIMAP) Research Centre, Pantnagar. Oils were evaluated at different concentrations viz 25ppm, 50ppm, $100 \mathrm{ppm}, 250 \mathrm{ppm}$ and 500ppm. Desired quantity of oil from stock solution was added to melted sterilised PDA media and poured in sterilised petriplates. Petriplates poured with sterisilised melted non toxicated PDA was taken as check. Three replications were maintained for each concentration. The $5 \mathrm{~mm}$ disc of test pathogen grown on PDA medium was placed at centre of petriplates containing different concentration of the poisoned medium and incubated at $28 \pm 2^{\circ} \mathrm{C}$. Radial growth was taken when maximum growth occurred in the control plates. The inhibition per cent of radial growth over the control was calculated by using formula given by Vincent (1947).

In vivo evaluation of fungicides, botanicals and essential oils: Four fungicides (Propoiconazole, Tebuconazole, Avtar and Captan), four botanicals (Lawsonia, Duranta, Turmeric and Eucalyptus), and four essential oils(Lemon tulsi, Clove, Citronella and Patchouli) which showed higher mycelial growth inhibition under lab conditions were selected and evaluated under glasshouse conditions as foliar sprays. The experimental design used was CRD. Artificial inoculation of pathogen was done by spraying spore sus- 
pension with spore load of $5 \times 10^{4}$ spores per $\mathrm{ml}$ by using an atomizer on foliage of maize at 30 days after sowing. The inoculated plants were kept in humid conditions for 4-5 days by preparation of moist chambers to provide favourable conditions for growth of pathogen. Observations on the severity of disease were recorded on 1-5 scale (Payak and Sharma, 1983).

\section{RESULTS AND DISCUSSION}

Evaluation of fungicides: Under in vitro conditions amongst systemic fungicides, propiconazole showed cent percent inhibition of mycelial growth, followed by tebuconazole(87.78\%) and least inhibition was observed with thiophenate methyl $(64.81 \%)$ at $10 \mathrm{ppm}$ concentration. At $20 \mathrm{ppm}$, $30 \mathrm{ppm}$ and $50 \mathrm{ppm}$ the similar pattern was observed as given in Table 1. Under glasshouse condition, minimum disease incidence was recorded from the pots sprayed with Propiconazole $(23.33 \%)$ followed by Tebuconazole $(28.50 \%)$ compared to disease incidence in control $(46.33 \%)$ as given in Table 3 . The results were in accordance with Wani et al. (2017) who observed that

Table 1. Mycelial inhibition of E. turcicum by different systemic fungicides.

\begin{tabular}{|c|c|c|c|c|c|c|c|c|c|c|}
\hline \multirow{4}{*}{ Systemic Fungicides } & \multicolumn{10}{|c|}{ Per cent inhibition of radial growth * } \\
\hline & \multicolumn{10}{|c|}{ Concentration } \\
\hline & \multicolumn{2}{|c|}{ 5ppm } & \multicolumn{2}{|c|}{ 10ppm } & \multicolumn{2}{|c|}{ 20ppm } & \multicolumn{2}{|c|}{ 30ppm } & \multicolumn{2}{|c|}{ 50ppm } \\
\hline & $\mathrm{G}$ & I & G & $\mathrm{I}$ & G & I & $\mathrm{G}$ & I & $\mathrm{G}$ & 1 \\
\hline Azoxystrobin $23 \%$ SC & 21.17 & 76.48 & 18.67 & 79.26 & 17.67 & 80.37 & 13.50 & 85.00 & 11.33 & 87.41 \\
\hline Thiophenate methyl 75\% WP & 40.17 & 55.37 & 31.67 & 64.81 & 27.50 & 69.44 & 23.17 & 74.26 & 19.67 & 78.15 \\
\hline Tebuconazole $25.9 \% \mathrm{EC}$ & 23.00 & 74.44 & 11.00 & 87.78 & 0.00 & 100.0 & 0.00 & 100.0 & 0.00 & 100.0 \\
\hline Propiconazole 25\% EC & 7.00 & 92.22 & 0.00 & 100.0 & 0.00 & 100.0 & 0.00 & 100.0 & 0.00 & 100.0 \\
\hline \multirow[t]{2}{*}{ Check } & 90.00 & - & 90.00 & - & 90.00 & - & 90.00 & - & 90.00 & - \\
\hline & \multicolumn{3}{|c|}{ Fungicide(a) } & \multicolumn{3}{|c|}{ Concentration (b) } & \multicolumn{4}{|c|}{ Interaction $(a \times b)$} \\
\hline SEM \pm & \multicolumn{3}{|c|}{0.72} & \multicolumn{3}{|c|}{0.72} & \multicolumn{4}{|c|}{1.61} \\
\hline CD at $5 \%$ & \multicolumn{3}{|c|}{2.04} & \multicolumn{3}{|c|}{2.04} & \multirow{2}{*}{\multicolumn{4}{|c|}{4.58}} \\
\hline CV & \multicolumn{6}{|c|}{9.76} & & & & \\
\hline
\end{tabular}

Values are mean of three replications, $\mathrm{G}=$ Colony diameter in $\mathrm{mm}$, I= Per cent inhibition

Table 2. Mycelial inhibition of $E$. turcicum by different Non-systemic fungicides.

\begin{tabular}{|c|c|c|c|c|c|c|c|c|c|c|}
\hline \multirow{4}{*}{ Non Systemic Fungicides } & \multicolumn{10}{|c|}{ Per cent inhibition of radial growth * } \\
\hline & \multicolumn{10}{|c|}{ Concentration } \\
\hline & \multicolumn{2}{|c|}{ 50ppm } & \multicolumn{2}{|c|}{ 100ppm } & \multicolumn{2}{|c|}{ 200ppm } & \multicolumn{2}{|c|}{ 500ppm } & \multicolumn{2}{|c|}{ 1000ppm } \\
\hline & $G$ & $\mathrm{I}$ & G & 1 & G & 1 & $\mathrm{G}$ & $\mathrm{I}$ & $\mathrm{G}$ & 1 \\
\hline Zineb $75 \%$ WP & 31.17 & 65.37 & 30.83 & 65.74 & 25.17 & 72.03 & 21.33 & 76.3 & 21.27 & 76.37 \\
\hline Captan $50 \%$ WP & 23.00 & 74.44 & 19.17 & 78.70 & 18.50 & 79.44 & 12.50 & 86.11 & 12.00 & 86.67 \\
\hline $\begin{array}{lll}\text { Avatar } & \text { (Zineb } & 68 \% \\
+ \text { Hexaconazole } 4 \%) & 72 \% & \text { WP }\end{array}$ & 12.83 & 85.74 & 6.23 & 93.08 & 0.00 & 100.00 & 0.00 & 100.0 & 0.00 & 100.00 \\
\hline $\begin{array}{l}\text { Curzate (Cymoxanil } 8 \%+ \\
\text { Mancozeb } 64 \% \text { ) } 72 \% \text { WP }\end{array}$ & 24.67 & 72.59 & 21.83 & 75.74 & 20.00 & 77.78 & 16.83 & 81.30 & 14.00 & 84.44 \\
\hline Check & $\begin{array}{c}90.00 \\
\text { Fungi }\end{array}$ & ide(a) & $\begin{array}{r}90.00 \\
\text { Con }\end{array}$ & - & $\begin{array}{l}90.00 \\
\text { (b) }\end{array}$ & - & $\begin{array}{r}90.00 \\
\text { Inte }\end{array}$ & $\begin{array}{c}- \\
\text { action }\end{array}$ & $\begin{array}{l}90.00 \\
\times \mathrm{b})\end{array}$ & \\
\hline SEM \pm & & & & 0.32 & & & & 0.73 & & \\
\hline CD at $5 \%$ & & & & 0.92 & & & & 2.07 & & \\
\hline CV & & & & & & 05 & & & & \\
\hline
\end{tabular}

Values are mean of three replications, $\mathrm{G}=$ Colony diameter in $\mathrm{mm}, \mathrm{I}=$ Per cent inhibition

Table 3. Effect of fungicides on disease incidence and disease severity of Northern leaf blight of maize under glasshouse conditions.

\begin{tabular}{llllll}
\hline S. N. & Treatments & \multicolumn{2}{l}{ Disease incidence (\%) } & \multicolumn{2}{l}{ Disease severity (\%) } \\
\cline { 3 - 6 } & & $\begin{array}{l}\text { 10 days after } \\
\text { first spray }\end{array}$ & $\begin{array}{l}10 \text { days after } \\
\text { second spray }\end{array}$ & $\begin{array}{l}10 \text { days after } \\
\text { first spray }\end{array}$ & $\begin{array}{l}10 \text { days after } \\
\text { second spray }\end{array}$ \\
\hline 1 & Propiconazole 25\%EC & 18.51 & 23.77 & 17.67 & 20.00 \\
2 & Tebuconazole 25.9\% EC & 23.33 & 28.50 & 21.67 & 24.00 \\
3 & Zineb(68\%)+ Hexacona- & & & & 26.00 \\
& zole (4\%) & 25.12 & 30.1 & 22.33 & 27.00 \\
4 & Captan 50\% WP & 28.76 & 35.28 & 23.67 & 37.00 \\
& Check & 38.25 & 46.33 & 30.00 & 0.73 \\
& SEM \pm & 1.36 & 0.99 & 0.86 & 2.30 \\
& CV CD at 5\% & 4.31 & 3.14 & 2.69 & 4.71 \\
\hline \hline
\end{tabular}


Bhatt, B. and Kumar, P. / J. Appl. \& Nat. Sci. 11(2): 257- 262 (2019)

Table 4. Mycelial inhibition of $E$. turcicum by different botanicals.

\begin{tabular}{|c|c|c|c|c|c|c|c|c|}
\hline \multirow{4}{*}{$\begin{array}{l}\text { Name of } \\
\text { Botanicals }\end{array}$} & \multicolumn{8}{|c|}{ Per cent inhibition of radial growth * } \\
\hline & \multicolumn{8}{|c|}{ Concentration } \\
\hline & \multicolumn{2}{|c|}{$5 \%$} & \multicolumn{2}{|c|}{$10 \%$} & \multicolumn{2}{|c|}{$15 \%$} & \multicolumn{2}{|c|}{$20 \%$} \\
\hline & $\mathrm{G}$ & I & G & I & G & I & $\mathrm{G}$ & I \\
\hline Lantana & 67.17 & 23.37 & 58.33 & 35.19 & 58.00 & 35.56 & 55.00 & 38.89 \\
\hline Marigold & 85.50 & 5.00 & 84.83 & 5.74 & 75.67 & 15.93 & 74.83 & 16.85 \\
\hline Duranta & 41.67 & 53.70 & 32.83 & 63.52 & 31.00 & 65.56 & 29.67 & 67.04 \\
\hline Eucalyptus & 40.67 & 54.81 & 36.67 & 59.26 & 35.50 & 60.56 & 32.50 & 63.89 \\
\hline Heena & 35.50 & 60.56 & 29.17 & 67.59 & 27.95 & 68.94 & 26.00 & 71.11 \\
\hline Ginger & 75.00 & 16.67 & 72.50 & 19.44 & 66.50 & 26.11 & 55.50 & 38.33 \\
\hline Ashok & 83.33 & 7.41 & 74.67 & 17.04 & 66.33 & 26.30 & 58.50 & 35.00 \\
\hline Turmeric & 50.83 & 43.52 & 43.83 & 51.30 & 36.67 & 59.26 & 35.67 & 60.37 \\
\hline Aloe vera & 85.00 & 5.56 & 82.67 & 8.15 & 79.67 & 11.48 & 77.67 & 13.70 \\
\hline Rudraksh & 66.17 & 26.48 & 55.17 & 38.70 & 46.17 & 47.96 & 37.17 & 58.70 \\
\hline \multirow[t]{2}{*}{ Check } & 90.00 & & 90.00 & & 90.00 & & 90.00 & \\
\hline & \multicolumn{3}{|c|}{ Botanicals (a) } & \multicolumn{3}{|c|}{ Concentration (b) } & \multicolumn{2}{|c|}{ Interaction $(a \times b)$} \\
\hline \multirow{3}{*}{$\begin{array}{l}\text { SEM } \pm \\
\text { CD at } 5 \% \\
\text { CV }\end{array}$} & \multicolumn{3}{|c|}{1.05} & \multicolumn{3}{|c|}{0.63} & \multicolumn{2}{|c|}{2.10} \\
\hline & \multicolumn{3}{|c|}{2.95} & \multicolumn{3}{|c|}{1.78} & \multicolumn{2}{|c|}{5.91} \\
\hline & & & & & & & & \\
\hline
\end{tabular}

Values are mean of three replications, $\mathrm{G}=$ Colony diameter in $\mathrm{mm}$, I= Per cent inhibition

Table 5. Mycelial inhibition of E. turcicum by different essential oils.

\begin{tabular}{|c|c|c|c|c|c|c|c|c|c|c|}
\hline \multirow{4}{*}{$\begin{array}{l}\text { Essential } \\
\text { oils }\end{array}$} & \multicolumn{10}{|c|}{ Per cent inhibition of radial growth ${ }^{*}$} \\
\hline & \multicolumn{10}{|c|}{ Concentrations } \\
\hline & \multicolumn{2}{|c|}{ 25ppm } & \multicolumn{2}{|c|}{ 50ppm } & \multicolumn{2}{|c|}{$100 \mathrm{ppm}$} & \multicolumn{2}{|c|}{ 250ppm } & \multicolumn{2}{|c|}{$500 p p m$} \\
\hline & G & 1 & G & 1 & $\mathrm{G}$ & 1 & G & 1 & $\mathrm{G}$ & 1 \\
\hline Lemon tulsi & 26.50 & 70.56 & 25.83 & 71.30 & 23.17 & 74.26 & 21.00 & 76.67 & 0.00 & 100.0 \\
\hline Patchouli & 29.67 & 67.04 & 29.67 & 67.04 & 29.50 & 67.22 & 23.83 & 73.51 & 21.50 & 76.11 \\
\hline Clove & 72.00 & 20.00 & 62.33 & 30.74 & 27.33 & 69.63 & 10.83 & 87.96 & 10.00 & 88.89 \\
\hline Ginger & 29.83 & 66.85 & 28.50 & 68.33 & 28.33 & 68.52 & 25.33 & 71.85 & 24.67 & 72.59 \\
\hline Citronella & 67.50 & 25.00 & 67.00 & 25.56 & 61.83 & 31.30 & 44.67 & 50.37 & 11.00 & 87.78 \\
\hline Palmarosa & 73.17 & 18.70 & 61.33 & 31.85 & 61.67 & 31.48 & 56.83 & 36.85 & 30.00 & 66.67 \\
\hline Geranium & 75.17 & 16.48 & 70.00 & 22.22 & 59.33 & 34.07 & 59.17 & 34.26 & 55.67 & 38.15 \\
\hline Turmeric & 31.83 & 64.63 & 25.67 & 71.48 & 25.00 & 72.22 & 23.67 & 73.70 & 22.50 & 75.00 \\
\hline Peppermint & 82.33 & 8.52 & 82.67 & 8.15 & 80.00 & 11.11 & 66.83 & 25.74 & 56.67 & 37.04 \\
\hline Eucalyptus & 81.17 & 9.81 & 80.00 & 11.11 & 79.00 & 12.22 & 73.67 & 18.15 & 52.23 & 41.85 \\
\hline Lemon grass & 79.33 & 11.85 & 72.67 & 19.26 & 70.67 & 21.48 & 62.00 & 31.11 & 40.00 & 55.56 \\
\hline \multirow[t]{2}{*}{ Check } & 90.00 & & 90.00 & & 90.00 & & 90.00 & & 90.00 & \\
\hline & \multicolumn{3}{|c|}{ Essential oils (a) } & \multicolumn{3}{|c|}{ Concentrations (b) } & \multicolumn{4}{|c|}{ Interaction $(a \times b)$} \\
\hline SEM \pm & \multicolumn{3}{|c|}{0.98} & \multicolumn{3}{|c|}{0.63} & \multicolumn{4}{|c|}{2.20} \\
\hline CD at $5 \%$ & \multicolumn{3}{|c|}{2.75} & \multicolumn{3}{|c|}{1.77} & \multirow{2}{*}{\multicolumn{4}{|c|}{6.16}} \\
\hline $\mathrm{CV}$ & \multicolumn{6}{|c|}{7.51} & & & & \\
\hline
\end{tabular}

Values are mean of three replications, $\mathrm{G}=$ Colony diameter in $\mathrm{mm}, \mathrm{I}=$ Per cent inhibition

two foliar sprays with systemic fungicide, Propiconazole 25 EC @ 0.1 per cent reduced the diseased intensity of Turcicum leaf blight of maize. Among non systemic fungicides, at 200ppm concentration, cent per cent inhibition was shown by Zineb+ Hexaconazole, followed by Captan $(79.44 \%)$ which was statistically at par with Curzate $(77.78 \%)$ as given in Table 2 . Under glasshouse conditions, Zineb+Hexaconazole showed minimum disease incidence $(30.1 \%)$ followed by captan $(35.28 \%)$ as compared to disease incidence in control (46.33\%).

Evaluation of botanicals: Among all the tested botanicals under in vitro conditions Heena gave better results at $5 \%, 10 \%, 15 \%$ and $20 \%$ concentrations. At $10 \%$ concentration Heena showed maximum inhibition of mycelia growth $(67.59 \%)$ followed by Duranta (63.52\%). Marigold showed minimum inhibition of mycelial growth (5.74\%). With increase in concentration of plant extracts there was increase in inhibition percent as given in Table 4. Manu et al. (2017) conducted an experiment to assess the antifungal activity of eleven plant extracts at three different concentrations and observed that increasing the concentration of botanicals increases efficacy of plant extract against E. turcicum. Under glasshouse conditions minimum disease incidence $(26.67 \%)$ was observed in pots sprayed with Heena followed by Duranta $(29.50 \%)$ compared to maximum disease incidence $(46.33 \%)$ observed in check. The results obtained were in accordance with Sharma and Sharma (2011) who observed that leaf extract of 
Lawsonia inermis (Heena) showed highest inhibitory activity against all tested fungi viz. Alterneria solani, Drechslera halodes (Helminthosporium halodes), Curvularia lunata, Dreschlera graminae, Fusarium moniliformae (ITCC no. 2927) and some other pathogenic fungi and bacteria. Lawsone (2hydroxynapthoquinone) is the most important constituent of the plant. Henna also contains flavonoids, sterols, tannins, saponins, tannic acid, gallic acid, etc. (Muhammad and Muhammad, 2005; Chaudhary et al, 2010) which may be responsible for antimicrobial activity. Sharma et al. (2012) found that the leaf extract of Durenta erecta show antifungal activity against many Aspergillus spp. and highest activity was observed against $A$. fumigatus. The presence of excellent amount of alkaloids, flavonoids, terpenoids, saponins and phenolic compounds leads to antifungal effect.

Evaluation of essential oils: Among all the essential oils tested at 25ppm, 50ppm, 100ppm, $250 \mathrm{ppm}$ and $500 \mathrm{ppm}$ under in vitro conditions, at $50 \mathrm{ppm}$ concentration Lemon tulsi oil was found the most effective in inhibiting the mycelial growth $(71.30 \%)$ followed by other tested essential oils as given in Table 5. The study also revealed that with increase in the concentration, efficacy of oils against fungus increases. Plants when sprayed with Lemon tulsi oil showed reduced disease incidence $(24.17 \%)$ followed by Clove oil $(27.07 \%)$ compared to disease incidence $(46.33 \%)$ observed in check.

These results were in accordance with Sethi et al. (2013) who studied antifungal activity of various oils against pathogenic fungus Rhizoctonia solani by disc diffusion method and observed that Lemon Tulsi oil showed maximum inhibitory effect. Kishore and Pandey (2007) observed that clove oil shows antifungal properties and is very effective in inhibiting the growth of various fungal pathogens. Clove contains a compound Eugenol which is responsible for its antifungal activity.

\section{Conclusion}

The present study concluded that fungicides are quite efficient in managing disease but plant extracts and essential oils can also significantly reduce the disease incidence such as Heena ( $L$. inermis) extract and Lemon tulsi (O. africanum) oil which have certain antifungal properties. Thus identification of the antifungal compounds from the plants extracts can be utilised in preparation of a new formulations which are able to manage the disease without causing any harm to the environment. So a systemic and well planned application of plant extracts and essential oils along with judicious use of fungicide can be of great help in reducing disease incidence and simultaneously keeping in consideration the human health and environmental safety.

\section{REFERENCES}

1. Carlos, D.L. (1997). Diseases of maize in south-east Asia relevance and management Abstract of the Symposium 'Indian Phytopath. Soc. Golden Jubilee. International Conference on Integrated Plant Disease Management for Sustainable Agriculture, New Delhi, p. 22.

2. Chaudhary G., Goyal S. and Poonia P. (2010). Lawsonia inermis L.: a phytopharmacological review. International Journal of Pharmaceutial Sciences and Drug Resistance, 2(2) 91- 98.

3. Harlapur, S. I., Kulkarni, M.S., Wali, M.C and Srikant Kulkarni (2007). Evaluation of plant extracts, bioagents and fungicides against Exserohilum turcicum (Pass) Leonard and Suggs. causing turcicum leaf blight of maize. Karnataka Journal of Agricultural Sciences, 20 (3): 541- 544.

4. Kachapur, M.R. and Hegde, RK. (1988). Studies on turcicum blight of maize (Zea mays L.) caused by Exserohilum turcicum (Pass.) Leonard \& Suggs with special reference to crop loss assessment. Plant Pathology Newsletter, 6(1-2): 33-35.

5. Kishore, G. K., Pande, S., and Harish, S. (2007). Evaluation of essential oils and their components for broad-spectrum antifungal activity and control of late leaf spot and crown rot diseases in peanut. Plant Disease, 91:375-379.

6. Manu, T. G., Naik, B.G., Sayipratap, B.R. and Balagar. M.S. (2017). Identification of Sources of Resistance against turcicum leaf blight of maize. Chemical Science Review and Letters, 6(24): 21002107.

7. Muhammad H.S. and Muhammad S. (2005). The use of Lawsonia inermis $L$ (henna) in the management of burn wound infections. African Journal of Biotecnology, 4, $934-937$.

8. Nene, Y.L. and Thapliyal, P.N. (1979). Fungicides in Plant Disease Control. Oxford and IBH Publishing House, New Delhi, pp 525-540.

9. Payak, M.M. and Sharma, R.C. (1983). Disease rating scales in maize in India. In : Techniques of Scoring for Resistance to Important Diseases of Maize. Indian Agricultural Research Institute, New Delhi, pp. $1-4$.

10.Sethi, S., Prakassh, O., Chandra, M., Punetha, H. and Pant, A.K. (2013). Antifungal activity of essential oils of some Ocimum species collected from different locations of Uttrakhand. Indian Journal of Natural Products and Resources, 4(4):392-397.

11.Sharma,A . and Sharma, K. (2011). Assay of Antifungal Activity of Lawsonia inermis Linn. and Eucalyptus citriodora Hook. Journal of Pharmacy Research, 4 (5):1313-1314.

12.Sharma, P., Khandelwal, S., Singh, T., and Vijayvergia, R. (2012). Phytochemical analysis and antifungal potential of Duranta erecta against some phytopatogenic fungi. International Journal of Pharmaceutical Sciences and Research, 3(8): 2686- 2689.

13.Smith, C. Wayne; Betrán, Javier; Runge, E. C. A. (2004). Corn: Origin, History, Technology, and Production. John Wiley and Sons. ISBN 978-0-47141184-0

14.Vincent, J.M. (1927). Distortion of fungal hyphae in the presence of certain inhibitors. Nature 59: 850 (cf: Karnataka Journal of Agricultural Sciences 20(3): 541 -544 . 
Bhatt, B. and Kumar, P. / J. Appl. \& Nat. Sci. 11(2): 257- 262 (2019)

15.Wani, T.A., Ahmad, M. and Anwar, A. (2017). Evaluation of fungicides, bioagents and plant extracts against Exserohilum turcicum causing Turcicum leaf blight of Maize. International Journal of Current Mi- crobiology and Applied Sciences. 6 (8): 2754-2762.

16.Wise, K. (2011). Diseases of corn: Northern corn leaf blight. Purdue University Extension Publication. Purdue University. 